\title{
Jesús de Polanco and the Prisa Group
}

\begin{abstract}
The main goal of this article is to present Jesús de Polanco's (1929-2007) successive business initiatives that culminated in the expansion of the PRISA Group (Promotora de Informaciones S.A.), which was the leading Spanish multi-media group of its time. As well as the interest that his career triggers, Polanco's biography allows us to address the relationship between the company and politics during the closing decades of the Franco dictatorship and the transition to democracy from a concrete perspective. Those were years marked by profound transformations, not only in the political life of the country but also in its economy, society and business structures that affected the entire communications media sector.
\end{abstract}

Keywords: Entrepreneur biography; Media; Politics and Economy

\section{Businessmen and politicians}

The relationship between economics and politics, between businessmen and politicians, between economic interests and political power in capitalist societies was already a worry of the classical philosophers and in more recent times, historians, political experts and economists - of various theoretical schools or methodological currents - who have accumulated different ways to approach the topic.

Corresponding author: e-mail: mercedes.cabrera@cps.ucm.es

Received 06 Sept 2017 - Accepted 31 Oct 2017

This is an Open Access article distributed under the terms of the Creative Commons Attribution-Non-Commercial-No Derivatives License (http://creativecommons.org/licenses/by-nc-nd/4.0/), which permits non-comercial re-use and distribution, provided the original work is properly cited, and is not altered or transformed in any way. 
For a time, structural interpretations were defended, on occasion, from very different presuppositions, some Marxist, others Liberal, where businessmen and politicians defended interests derived almost naturally and inevitably from their positions. The goal of the former was usually to get to the bottom of an obvious communion of interests or an assumed subordination of politics to economic power, while the latter insisted on a more or less radical autonomy of the two. In both cases, there was hardly any need to stop to analyse those relationships; it was enough, at most, to confirm the assumptions of the original ideas.

Debates such as those on the subject of the responsibility of the big industrialists and German bankers in the rise and arrival to power of the Nazism in Germany gave way to an ample bibliography that questions the simplest interpretations. On the fiftieth anniversary of the end of the Second World War, the topic exceeded the strictly academic framework and it was the governments themselves who promoted the creation of international commissions to explain the responsibilities of companies and banks during the Second World War, the benefits that were obtained by the expansive policies of the Hitler state and the availability of manual labour in the labour camps of the occupied countries. The Bergier Commission and the Volcker Committee made abundant documentation public which led to voluminous reports (Turner 1985, Hayes 2001, James 2001, James and Turner 2002, Wiesen 2001).

It is surely an extreme case. In Spain, business history has experienced considerable development over the last decades thanks to the works of economists and economic historians who have taken the time to analyse the trajectory of businessmen and businesses, both public and private (Martin Aceña 2002; Carreras, Tafunell, and Torres 2003). Social and political historians have made relevant contributions to the study of the economic elite relative to politics, for example, in the analysis of clientelism and caciquismo in the $19^{\text {th }}$ century. The 
Franco dictatorship, the workings of the networks and corporate groups inside the union structures of the regime and their relationship with an interventionist State were also studied. For the early years of the transition to democracy, it was the sociologists and the political scientists who started to analyse the adaptation of these organisations to the new political and social context. The historians joined later. The important part of the study of the conflict gave way to diversification in the fields of study, in some cases relative to culture and social areas, to some extent abandoning the traditional concern about power relationships (Pérez Díaz 1987, Baena 1999, Del Rey 2003, Pan-Montojo 2007, Cabrera and Del Rey 2011, Toboso 2017). However, dialogue between economic historians and political historians has not been common, therefore, on many occasions the relationship between businessmen and politicians has normally found itself out of the spotlight of the advances in investigation. That allowed them to keep their reductionist vision and left a space free for the proliferation of accusatory literature, inclined to exploit scandals demonstrating that "the usual faces" were behind the political scenes, the hidden interests who pulled the strings to perpetuate over avatars, changes, crises and political failures throughout time (Cabrera 1997, Juliá 1997, Pérez Ledesma 1997, Pro Ruiz 1997).

As the knowledge of the past and the present grows and improves, we are able to confirm the complexity of this topic and, above all, the need to leave simple ways of thinking behind. It is necessary to consider not only the type and the degree of economic development, and the peculiarities of the business structures but also the State itself as regards its building progress and the strength of its institutions as well as the existence - or not - of political and corporative representation channels in each case. It is not the same to address the question from the study of economic elites and their informal networks as it is from individual cases or to approach it 
from organised economic interests and their relationship with the political institutions. You do not establish the same links between businessmen and politicians in a liberal $19^{\text {th }}$ century society with a "minimum" State and the notables politics, where everyone probably shares spaces, as those in a developed capitalist society with an extended State and mass politics with a professional and separate political class. Those relationships are not the same in a plural society with political power as in an authoritarian, interventionist State, although the levels of economic development are similar and the business structures as well.

One of the fields that is most favourable to dialogue between economic historians and political historians is biographies of businessmen. It has coincided with a more general revision, not free from debate, about the contribution of the biographic genre to historiographic knowledge, to the various forms of understanding and their capacity to show discontinuity, contradictions and the uncertainties of reality (Ruiz Torres 2010). The addition of biographies allowed them to nuance, delve deeper and even review assumptions that had been generally accepted about the supposed absence of businessmen in Spanish history or their deeply rooted inclination to look for State protection vis-a-vis the development of competitiveness (Tortella 2000, Torres 2000). But beyond this, biographies are indispensible to study the complexity of relationships between economics and politics and they should be incorporated into the analysis of the more general processes of social and political development. The addition of biographies would be key for a reflexion on the generational changes in the business class, the surge or crisis of certain business cultures and the relationship with the development of the institutions of the State, as well as the consolidation or crisis of the political systems (Fernández Clemente 2004).

The elaboration of biographies of businessmen on many occasions depends on the availability of information, the existence, or not, of a personal archive and the access to business sources. 
Teresa Tortella, the director of the archives of the Bank of Spain in the 80's, called on all Spanish companies and Spanish banks to preserve and make their economic archives available to the public for investigators. Her request proved to be quite successful and it led to the publication of some business histories. It is not always easy, nor is the work of an investigator free from the suspicions that the results could be conditioned by the directives handed out by the company itself.

The pages that follow correspond to some of these questions and refer to an entrepreneur, Jesús de Polanco, in his historical context (Cabrera 2015). The information that is handled here was found in his personal archive; in the minutes of the founders' meetings, the board of administration and shareholders' meetings of the PRISA group, and in personal interviews with people who knew him, who worked with him or who were his friends.

His personal archive is different from a business archive. It is not catalogued so as to be available to the public. It is a mountain of papers and documents - all varying in character that the family has roughly conserved by subject matter. A large part of the archive is his personal correspondence. The letters are irregular in rate of recurrence however significant in understanding his character, his way of acting and his relationships with family and friends. For the development of his business initiatives they are relevant in relation to the introduction and creation of Santillana, the publishing house, his first great company, especially in its beginnings and its expansion throughout Latin America because it allowed him to work out his relationships with other members of the publishing world, as well as with politicians in many different countries. Nonetheless, we must keep in mind that after a certain point in time, that material is no longer a decisive source because the majority of his relationships were already taking place over the phone or in meetings and there is no longer any proof of them available. 
Something similar can be said about the minutes of the founders' meetings, the board meetings and the PRISA shareholders' meetings. The PRISA minutes are especially explicit and interesting for the very complicated early years: from the time of its creation in 1972 until the moment when they could begin publishing El País and while the so-called "shareholders war" - where political interests collided with business interests - lasted. In the end, Polanco's control over the group became clear and the expansion began. It was a period when legal regulation of the press, the radio and the television were subject to big reforms and progressive liberalisation, not free of political pressure (Fernández and Santana 2000).

The existing bibliography about Polanco was not very extensive (Imbert and Vidal Beneyto 1986, Cruz 1996, Martínez Soler 1998, García Ruiz 2000, Soeane and Sueiro 2000), although it could be bigger if the other scandalous literature were to be included - the literature where Polanco appears alone or as part of the hypothetical political-economic conspiracies (Díaz Herrera and Tijeras 1991, Cacho 1994, González Duro 2011).

\section{From the book to the written press}

Jesús de Polanco did not come from a family of great businessmen. He was born in Madrid in 1929. He was the youngest of six children. His father, who was from Santander, was the manager of a small company that sold products of the region of Santander in the capital. $\mathrm{He}$ also owned the Granja de Henar, a café on Alcalá Street that many of the intellectuals of the time visited regularly. He was in Santander when the civil war broke out but his wife stayed in Madrid for a few months until she was able to leave with her children. She fled to Valencia where they boarded a British hospital ship that took them to Marseille. The trip to get back into National Spain was complicated but they were finally able to join the rest of the family in the Cantabrian capital where they stayed until the end of the war. When the war ended they returned 
to Madrid. The Polancos were a middle class family and they experienced hardships after the father's death in 1942. Jesús had memories of all of those years: the war front in Madrid, the rhetoric and political propaganda of those who led the revolt, the hard post-war years along with his mother's austere and repressed mind-set. In that Spain, as was fitting for a very conservative family such as his, Jesús went to a school that belonged to Claretiana Cleric Order. He was Catholic, Falangist and was a member of both the Juventudes de Acción Católica and the Falange Juveniles de Franco.

Polanco studied law at the University of Madrid. It took him longer than normal to finish his studies and he was never interested in practising law. He started to work young and he married in 1954 before graduating. He also did his obligatory military service. He juggled various jobs that provided him with experience in the world of publishing magazines and books. First he worked at the Instituto de Cultura Hispánica on a Catholic magazine aimed at Latin America. After that, he worked editing theatre plays at Alfil, a publishing house that was later sold to another publishing house, Escelicer, where Jesús became the commercial manager. At the same time, he was the editor of Aduanas. Aduanas was a magazine founded by a group of civil servants from the Customs Corps, one of whom was his friend Germán Anlló. He was the administrator of the magazine Ateneo as well. Ateneo was a political publication that participated in one of the debates of the time that the various "families" of the regime were having on "the problem of Spain."

These jobs afforded him the possibility to meet writers and politicians of the dictatorship Manuel Fraga Iribarne, José María Pemán, Florentino Pérez Embid, Gonzalo Fernández de la Mora and Dionisio Ridruejo to name a few. Polanco struck up a friendship with Dionisio Ridruejo that gradually distanced him from the regime. The friendship also led to his meeting 
with many of the exiled Spaniards in Latin America once he had started up Santillana, his own publishing house. In fact, Polanco confessed on more than one occasion, that in 1962 he could not attend the meeting of the Europe Council called "The Munich Conspiracy" by Franco regime, where Liberals, Christian democrats and socialists all from the opposition to Franco both from Spain and in exile attended. Many of those attending were banished and exiled.

Although he had had inclinations as a young combative journalist and wrote in a few Catholic union publications that had social leanings, he soon realised that he had a penchant for undertaking projects. He decided to leave Escelicer to start up a distributor of his own books. He named it "J.P." using his own initials and he was the sole employee. He ordered the books, packaged them up and sent them. However he had something more ambitious in mind. His experience as a distributer to a Mexican bookstore came in handy. This path was opened up to him by one of his brothers who had emigrated to that Latin American country.

It did not take long for Polanco to turn "J.P." into another company, Santillana. He was the majority stock holder as well as the president of the board of administration, CEO and manager. The decisive event was when Francisco Pérez González, Pancho, joined the company. Pancho was a bookseller and distributor from Santander, founder of the publishing house Taurus and importer of books from Latin America. A lot of the books imported from Latin America were forbidden in Spain and had to be sold under the counter even though Pancho himself was quite conservative. In addition, he knew the trade of editors and booksellers well both in Barcelona and Madrid - the two book capitals - as well as the ins and outs of the vertical union and the Instituto Nacional del Libro.

The combination of Jesús' entrepreneurial spirit and Pancho's capacity to network was crucial for the success of Santillana. Likewise, the end of the autarchy and the relative opening that 
followed the Stabilisation Plan with the beginning of economic growth and subtle social modernisation along with an increase in the middle class also contributed. It was the beginning of the 1960s and business initiatives in the Spanish publishing sector were multiplying after the regression that had taken place during the post-war period. Some of the traditional publishing houses were revived and new ones born. The Latin American market that had been important throughout the first decades of the century began to recover and was now indispensable to enlarge the still limited Spanish market. The exile of intellectuals, writers and publishers to those countries had contributed to the growth of important publishing houses in Mexico and Argentina. Through their accumulated knowledge they now were helping the Spanish houses to reawaken although their competition did complicate expansion to those countries. The Spanish publishers managed to add their commerce to the pressing interests of the first Plan de Desarrollo (Development Plan) to include concessions of increasingly important official export credits. Pancho Pérez González was the person in the company who had to obtain it from Minister López Rodó (Martínez Martín 2015, Fernández Moya 2015, Sánchez Illán 2015). Jesús de Polanco and Pancho Pérez travelled the route back and forth across the Atlantic several months a year to visit the various Latin American countries. Their suitcases were full of books and they signed contracts with booksellers and publishers and expanded the credit system of payment that Polanco knew well. It was hard work that their letters to each other clearly reflects. Santillana distributed books to other publishing houses but it soon began to publish its own books, mainly to the somewhat easier market of books for children and young people. Their big opportunity came with the expansion of educational books for the adult literacy campaigns, first in Spain and then in Latin America, and afterwards with the education system reforms fostered by UNESCO. 
Polanco later said they were living a "legitimate education psychosis." He saw it coming and ran the risk to take an important business jump. Santillana leaped into the production of text books in a modern format that was very different from the old notebooks and scholarly encyclopaedias. These new text books had attractive designs and were put together by their own interdisciplinary groups. They used marketing campaigns, visited schools, held meetings with teachers and directors of schools, visited people responsible for education, educators, ministers and even heads of state. It was exhausting. It was not easy to crack the competition they faced from some of the Latin American publishing houses that had official protection. Polanco decided to create publishing companies in those countries instead of branches of the Spanish central office. These companies were independent and employed people from the country they were set up in, but their key to success lay in the fact that they adhered to Spanish ways of working.

At the end of the 60s they were firmly established in Chile through Santillana del Pacifico and had managed to get contracts in other countries. When a new general education law was passed in Spain in 1970, their soundness and experience allowed them to quickly respond to the new study plans with a competitive offer. Thousands of books left their offices and warehouses on Elfo Street every day testing the strength of the company. Polanco signed on Adolfo Valero and Javier Baviano who had studied law and economics with the Jesuits. This was not the usual type of training for the staff of publishing houses of the time.

By the beginning of the 70's Polanco was already a recognised publisher thanks to the success of Santillana. In a meeting with directors at the end of 1971 Polanco told them that they should continue working to make it the number one publishing group in education in the Latin American world. Ten years had passed since it had been founded. The success of school books 
threatened to make the rest of the company's activity disappear so Polanco decided to separate it from the rest of the company's activities. He left it under the management of his indispensable colleague Emiliano Martínez. Martínez was a pedagogue who had been a valuable collaborator right from the beginning. Polanco founded a new company called Timón that was in charge of designing the more general strategy. $49.9 \%$ of Timón's shares went to the Polanco family, $32.78 \%$ to the Pancho Pérez González family and the remaining shares went to other lesser partners including Emiliano Martínez. In the 80's a real publishing group was created from Timón through the purchase of other companies that were having trouble: Taurus, Alfaguara and lastly Aguilar. Not all of the acquisitions had good economic results. The base for economic solvency was always Santillana while the others provided Polanco with prestige and consequently greater importance among Spanish and Latin American writers and intellectuals. By then, however, he was devoting the greater part of his efforts to another company; one that he had entered as just one more of so very many modest shareholders. In 1972 José Ortega Spottorno had asked him, just like he had asked other publishers, to join the recently created PRISA. They knew each other because José Ortega was also a publisher and had enjoyed great success founding Alianza and its collection of paperbacks. Ortega had been mulling over the idea to launch a daily newspaper for a long time. The timing was perfect: the end of the Franco dictatorship was in sight and the daily papers were not reporting on that political and intellectual excitement. The newspaper Madrid experienced the arbitrariness of the press law when it was applied to them in 1966 because of its blunder they had made. Weekly magazines such as Triunfo, Cambio 16 and Cuadernos para el Diálogo or newspapers like Informaciones barely covered the space that an economic, independent, quality, modern newspaper with European aspirations like the French paper Le Monde could fill. That is what Ortega thought. He felt that 
his family's liberal, $19^{\text {th }}$ century experience, and the intellectual role of his father, the philosopher José Ortega y Gasset known from the first decades of the century, backed him. His son now enjoyed enough prestige among those in the publishing world, intellectuals and politicians to give this adventure a try. So PRISA was born. Polanco was one of the people Ortega Spottorno called on for money; not much at first because the independence of the future newspaper had to be based on dispersion (Cabrera 2016).

When PRISA's first shareholders' meeting was held in January 1972 the registration of El País in the Registry had already been requested. Governmental authorisation was an indispensable requirement at that time to publish a newspaper and in the case of El País that authorisation was delayed for almost four years. To justify the delay the authorities demanded an increase in capital. It had been difficult to go from the 500.000 pesetas initially requested to 15 million pesetas and the government was demanding 150 pesetas. It was not easy to get the money because many were convinced that the newspaper wouldn't get published unless Franco died. The group of three co-founders, José Ortega Spottorno and the journalists Darío Valcárcel and Carlos Mendo looked for help in the circles that they moved in. Ortega sought help from publishers, writers and intellectuals, Valcárcel, from political monarchists and Mendo from amongst Fraga's supporters and other liberals in the regime. Well known names of moderate enemies to the regime, professionals, (lawyers, architects, doctors, engineers), writers and some businessmen were slowly added to the list of contributors.

Polanco's implication in the project came in steps. Mendo, in pectore director of the newspaper, went to London following Fraga who had been named ambassador. Ortega asked Polanco to join him and Valcárcel on the executive committee. Polanco accepted. It was the first step. They had bought a lot and had started to build on it but despondency spread as they faced the 
government's silence and they even considered abandoning the project. Polanco kept hope alive but insisted on the need to use the resources and machinery available in the meantime to avoid damage and so that they would be ready when the authorization finally arrived. The authorization finally arrived in September 1975 shortly before the dictator died with the condition attached that they wait until the moment of Franco's death before making it public. Only then did Jesús de Polanco agree to become CEO as Ortega had asked.

From that time on and until its release date on May 14, 1976, it was all hands on deck. Polanco made the decision to change the printing press they had bought for one with greater capacity in order to print more copies. The newspaper that Polanco envisioned coincided with Ortega's idea in many aspects but Polanco wanted it to have the widest circulation of all newspapers. With that idea in mind Polanco went to Yuste Street every day where he received visits from many of the outstanding politicians of the time, who he had invited, and explained the project to them; supervised the works and designed the structure of the company that was going to have two fundamental pillars: Javier Baviano, who he brought with him from Santillana to be the manager and Juan Luís Cebrián as director. The executive committee discussed a long list of candidates for the job of director until the three of them agreed on Cebrián. Cebrián was not well known however he was a young journalist with an important career path already to his name. He had been chief editor at Pueblo, a newspaper belonging to the Movimiento, he had also worked at Informaciones and he had been director of the public television's news programmes in 1974.

\section{The radio and the television}

It did not take long before El País became the newspaper of reference, "the organic intellectual of the Transition" as the philosopher José Luis López Aranguren called it. But the road was 
not easy, the first years accumulated losses and Polanco loaned it money even to pay salaries. The result was not guaranteed either. In fact, the majority of newspapers experienced great economic difficulties and many of them that had appeared ended up shutting down. The success of El País was the consequence of the configuration of a modern business model designed by Polanco and a journalistic line that Cebrián set and whose independence Polanco guaranteed. Some cadavers were left along the way. Both José María de Areilza and his monarchists and Fraga and his followers saw the appointment of Adolfo Suárez as president of the government and the results of the first democratic elections, the victory of Unión de Centro Democrático, (UCD), and the emergence of the Socialist Party (PSOE), as the leader of the opposition as troublesome setbacks to their aspirations. They fought the political battle in the newspaper and they lost in a succession of tempestuous general shareholder meetings that lasted for hours and were a real show. The support that Polanco and Cebrián received from the president of the company, Ortega Spottorno, after doubts and debates was fundamental.

The increasingly positive results of the newspaper's daily circulation (reaching 250,000 copies in 1981), and the benefits, (384 million pesetas that year), although the dividend sharing took a while in coming because Polanco reinvested, played towards the final victory. Some of the early shareholders criticised him because they considered the growth of the company to be excessive considering the initial project, but Polanco fought to make El País the leading newspaper without detriment neither to its quality nor to its independence. Cebrián was his best ally here. Polanco bet and risked but in a controlled way. As he said on many occasions, he was "an old school" businessman whose culture was based on austerity, reinvestment of benefits and paying off credits immediately. That had also been the philosophy of Santillana. 
Polanco brought a tireless rhythm to El País with the successive increases in capital, a multiplication of the number of presses and the incorporation of all of the technological novelties. On the fifth anniversary of the paper they inaugurated a second building and generalised the use of computers. They had also launched an edition of El País in Barcelona. PRISA used the subsidies that the State had arbitrated to facilitate the modernisation of newspaper companies, but as Polanco sharply pointed out to those who criticised him, they all had equal access to the subsidies. While the rest of the press carried serious problems derived from their obsolete installations and personalisation of their business structure, El País grew and became an object of desire and also a centre of attacks. The newspaper presuming about its success certainly did not help to defuse tension.

Proof of the tough battle can be found in the minutes of the meetings and board meetings. It did not take long for important buying and selling of shares to take place. These movements were not always transparent nor did they always meet the prerequisites set out in the company's statutes. Antonio García Trevijano underhandedly attempted a coup to take over the newspaper, even trying to involve Cebrián. But Jesús de Polanco was also buying up shares using Propusa and Presa, two companies owned by his family and friends. This was announced in the founders' meeting of the newspaper in May 1983. That is where the "shareholders war" ended. Polanco gained control of the majority of the shares. He later said that that had not been his intention but that it was the only way to guarantee the survival and independence of the newspaper.

The initial model of capital distributed among many small shareholders no longer existed and PRISA's horizons expanded. That is how José Ortega Spottorno understood things when he resigned to become the president of honour. Jesús de Polanco became the executive president. 
In an article published in El País entitled "A worthwhile adventure," ("Una aventura que mereció la pena", June 20, 1984), Ortega explained that he left because there was someone who could replace him, someone younger and with greater ability, Polanco, "a leading business temperament" who had led El País to a position envied by many of the world's greatest newspapers. The company was going to access other communication media such as radio and television and Polanco was the right person to lead this process.

Meanwhile, an important twist took place in political life. The PSOE won the general elections in 1982 by an overwhelming majority. Hence began what was going to be the Socialists prolonged stay in power because they ratified their majority in 1986 and 1989 albeit losing some votes. They reached power promising "change" and Spain changed for sure. Once they got past the economic crises of 1973 and 1979 they finished the fiscal reform that UCD had started, they propelled a reorganisation of the bank, and industrial reconversion that not everyone agreed with and they started privatising public companies; there was a reform of the labour market that cost the government a general strike that paralyzed the country; the Socialists revised their previous position so as to keep Spain in NATO and finished off by incorporating Spain into the European Economic Community.

Regarding the media, the PSOE continued along the path initiated by the first governments of the transition and established a new legal regulation for the media, from the definitive demolition of the network of State newspapers to the concession of new radio stations, the elaboration of a statute for public television and the liberalisation that the appearance of autonomous and private television stations meant for the country. None of these actions were free from controversy and if there seemed to be a good relationship between the Socialists and the media at first that first impression gave way to growing confrontation. The sector 
experienced accelerated competition where the political battle interfered with business intentions.

In this context of change and controversy, PRISA entered into the radio. The first attempt proved insufficient after the concession of a station in Madrid, Radio El País, Polanco decided that the right route to follow was to take control of one of the already established stations. He found his opportunity in one of the most renowned stations in the private sector, the SER (Sociedad Española de Radiodifusión). The director was Antonio Fontán; the president was Antonio Garrigues Díaz Cañabate. The station was experiencing serious financial difficulties. The purchase of two packages of shares allowed Polanco and other representatives from PRISA to become members of the board of administration and they started to clean up the company and ended up owning the majority of its shares. It was a tough fight and publicly controversial, especially for the Fontán family, although Antonio Garrigues supported Polanco. They created programmes that reached maximum audiences in their time slots and once Augusto Delkader took over management the station paid special attention to the news programmes. In 1987 the results showed benefits and the modernisation of the station ended two years later once the remodelling of the building that housed the central headquarters on Madrid's Gran Vía finished. By that time, there was yet another turn in the long and complex road that was the process of legal regulation of private television. It was a question that especially worried the political world because control of the television had a much greater political impact than the newspapers or radio did. They did not know much about the matter not just in Spain but also in Europe where they were living that same process of the proliferation of private initiatives.

In Spain there was soon news of negotiations and projects from various media companies and publishing houses, among them PRISA who had created a new company, Sogetel. El País 
continued to show increasingly greater profits but a television station would need many more resources and a different business structure as well. Polanco closely followed the political debates and had access to those who could keep him informed about the mood inside government where not everyone was in agreement. The concession of private television stations had not been in the PSOE's electoral programme and now they at least wanted to try to guarantee pluralism by avoiding the concentration of property especially in the hands of the news media. Polanco had also gotten hold of reports on the viability of private television stations in relation to the advertising market.

The law regulating private television was finally passed in April 1988 but Polanco announced that PRISA was not going to appear. In his opinion, the law was behind the times technologically because it did not contemplate the development of satellite or cable television; it imposed unjustified restrictions especially on the news media and it obliged them to compete at a disadvantage with public television in the advertising market. What Polanco did not say was that he had not abandoned the idea but rather that he was contemplating another alternative and was preparing, in parallel, a restructuring of the group.

He presented a change in the structure of PRISA to the board in October 1988. It was passed by the shareholders' board in the spring of the following year. Juan Luis Cebrián became the CEO while Polanco stayed at the helm as executive president. Cebrián left the direction of the newspaper and Joaquin Estefanía took over. Polanco explained to the shareholders that the change was necessary so that PRISA could continue developing in the sector, alone or in the company of others, and at the same time preserve the influence and prestige El País had obtained. It was necessary to separate it from the other activities and to do that he constituted El País S.A. keeping the same advisors as in PRISA. He created two divisions in the group; one 
audiovisual where he included the SER, Sogetel and Canal+, and another publishing division that grouped various book publishers and magazines together: Edipaís, Progresa (El Globo, Claves de Razón Práctica) and Estructura, (Cinco Días, Mercado). PRISA had become a holding company.

Some months later when the tendering process for the allocation of the, expected, three private television channels became public, the surprise took place. The awardees were Telecinco (the ONCE, the publisher Anaya and Berlusconi's Fininvest participated), Antena3 (lead by Count Godó with the participation of Antena3 radio and Prensa Española that published the $A B C$ newspaper), and Canal+, the new company owned by PRISA. The surprise was that Canal+ was proposing pay TV. They had been preparing this from the time they had received the offer to collaborate from Canal+ France. PRISA and Canal+ France held 25\% of the capital which was the maximum allowed by law; the Bilbao Vizcaya Bank held 15\% each and Bankinter, Caja Madrid, Construcciones y Contratas and Eventos S.A. (a company linked to El Corte Inglés) held 5\% each.

It did not take long for the comments to start. The newspaper $A B C$, that had been leading a campaign against the PRISA group and they had nicknamed El País "the government's" newspaper, said that it was "a prize for services rendered" to the government from the "devotee" newspaper. The spokesperson for the PP party in Congress, the main opposition party, voiced comments to the same effect. However, those same people who were criticising PRISA also predicted a categorical failure because nobody in Spain was going to pay to watch television, especially when there were other choices available such as those the public autonomous channels and the new private channels were offering. 
Juan Cueto was the director of Canal+. He was enthusiastic about pay TV and had convinced Polanco and Cebrián. In his opinion, five general, public channels and three private channels were a lot and that there was not enough advertising to keep them going. Pay TV already had several million subscribers in Europe. It was an additional ticket window to movie theatres, sports arenas or bullrings. That is just what Canal+ did. It devoted its' programming to all types of sports including soccer. Broadcasting football had to be negotiated with the professional football league and broadcasting gave football a face-lift. Broadcasting premiere cinema was another programming initiative that had to be negotiated with the large production companies and the worldwide film distributors, especially the American ones. None of these wagers were cheap. Nevertheless, three years later, in the spring of 1992, Canal+ had 665,000 subscribers and Polanco could tell the shareholders that it was a success and that they had already reached financial balance.

\section{In the eye of the hurricane}

Jesús de Polanco had reached a place that he had never dreamed of reaching. PRISA was the most powerful media group in the country. Without a doubt Polanco was proud and he did not exercise discretion when speaking. He liked power and he showed it, although he said that he liked power because it let him undertake new projects. He was a passionate follower of the changes that were taking place in the media world. He saw the increasingly harsher and more numerous attacks directed at him as proof of how jealous people were of his success and a consequence of the corporate competition in the sector. He was outraged that they had labelled him a servant of the socialist government because he was zealous about his independence. From a personal and generational point of view, he felt closer to the politicians in UCD although he was friends with many socialist politicians. But he was not a socialist. The fact that his readers 
and listeners voted socialist was, in his opinion, a coincidence, a result of social transformation and the success of his media. That was one thing and quite another that the successive, successful business initiatives he had set up were the result of government favours. El País was certainly not a result of government favours and neither was the purchase of the SER as the fact that the socialist government refused to sell him $25 \%$ of the State owned shares for several years demonstrates. This was a measure that had been introduced in the early years of the transition. The vice president of the government, Alfonso Guerra did not think highly of Polanco and it was not until Guerra resigned that Polanco obtained the State shares.

Polanco knew very well that the concession of a licence to Canal+ had caused controversy at the heart of the government because Vice President Guerra and his followers were flatly opposed to strengthening PRISA's power. Polanco had an audience in Felipe González but they did not become personal friends until after González left power. El País and afterwards the SER defended very critical opinions about some of the government's policies, especially those related to media policies and public order. In fact, the Minister of the Interior, José Barrionuevo, took them to court. Polanco and PRISA had had confrontations with the so-called guerrista sector of the party who were suspicious of his power and had placed Polanco on the list of those people who they referred to as "the beautiful people;" a group of bankers, entrepreneurs and businessmen who had become prosperous thanks to the country's economic growth and who had been supposedly protected even by some socialist politicians with whom they had tight connections.

The PSOE won the 1989 election by a slim majority against a Partido Popular under the new leadership of José María Aznar who had anticipated better results. The outbreak of a series of scandals that especially affected the Socialists set off a period of escalating political tension. 
Talk of corruption inflamed the air waves of the radio talk shows and led to what was referred to as "investigative journalism" and scandalous tales that revealed alleged plots of interests between businessmen and politicians. In the summer of 1992 a new intervention by the PRISA group fired up the air waves again. Many rumours started circulating about Antena3. The company was in a bad economic situation because of its' multimillion peseta debt with the Caixa bank and there was considerable speculation about the consequences when it was announced that PRISA and the Godó group had reached an agreement for the SER and Antena3 radio to collaborate. Some of the radio stars of the time left Antena3 slamming the door in Polanco's face while denouncing what they called an "antenna suicide," (antenicidio). They found homes either at the COPE, the radio station owned by the Episcopal Conference, or at $E l$ Mundo, a new newspaper under the management of Pedro J. Ramírez. El Mundo was notorious for its grievances and criticism of both the socialists and the PRISA group. That year, PRISA turned 20 years old and Polanco celebrated that anniversary as a combination of an intellectual project and a business reality in full development. That year, they billed 90,000 million pesetas. When they announced the merger of the SER and Antena3 Radio into Unión Radio in November their critics took the case to the ministry of the economy because they considered it an economic concentration that threatened freedom of speech and the Competition Defence Tribunal (Tribunal de Defensa de la Competencia), imposed severe conditions on the merger. Against the odds of most, the PSOE won the 1993 election even though they lost their absolute majority. The tension grew. PRISA's board of administration went to the defence of its president and Polanco himself, always reluctant to do so, felt obligated to grant several interviews but always to media unaffiliated with his group. He defended his actions and denied the majority of the accusations: that PRISA had a monopoly in the media. There were no large 
companies in Spain; they were nothing more than a "big dwarf," (un enano crecedito), in comparison to the large companies in other countries. He said this because there were the companies that he was comparing his to and his horizon was the Spanish-speaking world.

El País celebrated its $20^{\text {th }}$ birthday a few days after the Partido Popular won the 1996 general elections. The anniversary was celebrated in style. The outgoing president of the government, Felipe González, and several of his ministers attended plus the incoming president, José María Aznar, with some of the prominent figures of his new government. Jesús de Polanco showed off PRISA's economic strength as well as its independence and professionalism. A few months later they announced the launch of a digital pay platform, Canal Satélite Digital, by means of the creation of a company, Sogecable. It was another forward leap that arrived after tough negotiations and agreements that concluded in an agreement with Antena3 Televisión.

The government reacted by promoting the creation of another platform, Vía Digital, backed by the telephone company, Telefónica. In addition, they accelerated approval of the cable television law, approved a royal decree that established a series of technical demands along with the registration of decoders and announced another law that declared football to be "of general interest" thereby striking down the exclusive rights to broadcast matches on pay per view TV. El País repeatedly reported measures that they considered to be aimed against the PRISA group. The last straw was when Judge Gómez de Liaño accepted the lawsuit filed by Jaime Capmany, a journalist working at the $A B C$ newspaper, against Sogecable's chief executive officers accusing them of irregular use of the subscribers' money. Jesús de Polanco, Juan Luis Cebrián and the members of the boards of Sogecable, the Banco Bilbao Vizcaya, the March group, Caja Madrid and all of the other participating companies had to appear in the National High Court. 
There was a sharp turnaround in the case and the judge ended up being sentenced for perversion of justice by the Supreme Court as a result of the lawsuit filed by the defendants. Nonetheless, 1997 was a dreadful year for Jesús de Polanco. It had been a corporate battle but above all, political battle, where a private company had measured its forces with a government. PRISA and Polanco withstood but they paid a high economic price but by putting El País and the SER to the service of what many considered purely corporate interests, and sacrificing the neutrality that was owed to their readers and listeners their credibility all but disappeared. The accusations of arrogance hurled against PRISA's media and Polanco himself hit home, pressure from above made Antena3 Televisión change alliances. They joined the government's digital platform leaving PRISA and Telefónica in a position of confrontation. Telefónica had incomparably greater resources, plus, its president, Juan Villalonga, was a personal friend of the president of the government. Telefónica launched a limitless expansion policy.

\section{“Acquire size:" the number one Spanish media, culture and entertainment group}

In 1998 Polanco closed the "Sogecable case" and flexed his muscles: he bragged that PRISA's business figures had increased $17 \%$, that net profit was a consolidated $10 \%$ and that there was a distribution of dividends equal to their social capital. He affirmed that he continued betting on growth, but not at any price and not unpredictably; but rather on diversification of investment through internationalisation and new technologies and he wanted "strong, stable partners with a deep understanding of the sector." First with Canal+ and much later with Canal Satélite Digital, PRISA had entered the era of alliances with large companies and banks and credit resources and indebtedness. Some began to call this "financiarización" (Almirón 2006).

The Spanish economy was going through a period of euphoria and the government of the Partido Popular was imposing a new style. The privatisation of the large public companies 
allowed the government to place people of their confidence at the head of the companies; one might say a new business class targeting foreign markets, especially the Latin American market. At the same time the government boasted about fomenting "popular capitalism" through the sale of shares on the Stock Exchange, which by volume placed, reached a historic record between 1997 and 2000.

In July 1999 Polanco decided the Initial Public Offering, IPO, of Sogecable which triggered a campaign against him by the usual critics, about the Sogecable's hypothetical insolvency. It is true that Sogecable had 94,000 million pesetas in credits. However, the IPO went well because they were still living in the bubble created by the technological companies, the so-called dotcoms. It was a risky bet because they were the number one telecommunications company to do that but they did it successfully and $A B C$ calculated that the shareholders earned 60,000 million pesetas in capital gains.

Some months later, the Partido Popular won the elections and this time they won an absolute majority "against all odds" as El País dared to write. Only five days later, Polanco announced more changes at a time that he said was of "historic importance". The old formulas were useless already because the challenge that faced them demanded fast and accurate answers. To compete in a globalised world and meet the challenge of international projection and the new media technologies they had to "acquire size". To this end he proposed to integrate Santillana into the group and take PRISA public. Integrating Santillana meant gaining size and an important projection in Latin America which would make PRISA a "media, culture and entertainment group." On the other hand, by going public they would become stronger, attract more resources and they would be in better shape to safeguard their independence. 
With that proposal Polanco changed his business philosophy definitively. He was always reluctant to include Santillana because it had always been his safe haven and because he thought that it was enough that the relationship between PRISA and Santillana was channelled through Timón. It was Cebrián who convinced him to do it. Santillana was valued at 18,000 million pesetas and that figure raised criticism from some advisors who thought that it was overvalued. There was also criticism of the bonus given to Cebrián - the equivalent of one point of the shares in portfolio, $18,562,000$ pesetas.

The decision to go public broke away from the culture of the group because it meant unknown shareholders, who could gain control of the company, could enter. After much debate, they decided that the company, Diario El País, would not be included, that it would become a limited liability company and would be subject to the Fundación Santillana. That foundation created by Polanco years before and controlled by the family and their closest friends, would always own shares that would give them the right to vote. Thusly Polanco ensured that the autonomy of the newspaper would be preserved "from any foreign or hostile invasion of equity." Furthermore, Polanco also decided that it was necessary to institutionalise PRISA. He approved the appointment of his eldest son, Ignacio de Polanco, to the position of deputy president, thereby joining the corporate centre of the group. His daughter Isabel was also a member of the board of administration and one year later his other son, Manuel, would also become a member. In the middle of PRISA going public the Supreme Court found that the licence to merge the SER and Antena3 radio, granted years earlier, could be annulled thereby forcing Unión Radio to get rid of the 79 stations owned by Antena3. The media commotion was such that PRISA was about to back out the decision of going public. The obligatory information about it attributed PRISA a market value between 3,774 and 4,704 million euros. The demand for shares 
was eighteen times greater than the initial offer. It was a total success. Polanco appeared in magazines as the wealthiest man in Spain, even ahead of the banker Emilio Botín. He told a friend that it obviously was not true. They attributed the value of the shares he controlled not those that were actually his.

One of those magazines correctly ran the headline "Polanco's dilemma": PRISA could be too big for Spain and too small for the global market. Before going public they had carried out some significant operations. They were the first group among the Spanish media groups at the time and the group that had undertaken a more aggressive expansion strategy. They multiplied participation and acquisition of companies in Spain, Portugal and Latin America, not in the written media, but in radio and television, although PRISA's most solid base still lay in their "mature" businesses, in Santillana, in El País and in the SER. Polanco insisted that they would have to "acquire size" if they did not want to languish.

In May 2002, the president of Telefónica, César Alierta and Jesús de Polanco announced a merger of their digital platforms. The transaction was made through a capital increase of Sogecable of almost 58,000,000 euros, subscribed integrally by Via Digital. Telefónica became the most important share holder with $22.23 \%$ of the shares. PRISA and Canal+ Francia only held $16.38 \%$ but had equal representation on the board of administration. As a consequence, the "war of the platforms" ended. Although the most radical wing of the press said that the government had sold itself out and that it was the biggest success of Polanco's career, Sogecable's absorption was long and costly. The stock markets were punishing telecommunication companies and what's more, they discovered that Vía Digital had been overvalued. Its number of subscribers and business figures were much lower than those that they had shown during the merger process. Despite that, Polanco stuck to his conviction that 
the base would stay strong if they acted with "realism" and if the necessary adjustments and disinvestments were undertaken.

In March 2004 he announced that he was leaving the presidency of Sogecable. His resignation was part of the deal to reach an agreement with Telefónica. Nonetheless, he left with the satisfaction of a job well done. A few days later, on March 11, Madrid suffered the most tragic terrorist attack in its history in the Atocha, Santa Eugenia and el Pozo del Tío Raimundo train stations. One hundred ninety two people died. The Aznar government was adamant that ETA had been responsible. That fatal mistake was the last straw and it cost them the election. The Socialists won and the new general secretary of the PSOE, José Luis Rodríguez Zapatero, became president of the government. In his electoral programme he had included the commitment of a new legal regulation for the audiovisual media both for public television to ensure political neutrality as well as for private channels to face the reality of digital TV. There was a new law in June 2005, a real revolution starring digital terrestrial television, TDT, and the authorisation of two new analogical channels: the Sexta and the Cuatro. The Cuatro was part of the PRISA group, the result of a modification of the contract with Sogecable to eliminate restrictions on free-to-air programming. Polanco already had what he had always dreamed of: free-to-air national television. Soon the voices that accused him of favouritism were heard again but the fact is that the Cuatro had to compete hard and the relationship with the Rodríguez Zapatero government was not an easy one.

\section{Jesús de Polanco's farewell}

In 2004, Jesús de Polanco celebrated his $75^{\text {th }}$ birthday. PRISA had been organising the Ortega y Gasset awards for journalism since 1984. A few months earlier Polanco had missed the award ceremony for the very first time. He had been in Boston getting treatment for a problem he was 
experiencing in his cervical vertebrae. The problem required a long treatment. Nonetheless he travelled to Latin America in 2005, something that he had not done since the early days of Santillana. However, in 2006 he missed the Foro Iberoamericano (the Ibero-American Forum), a space for debate among businessmen, intellectuals and politicians which, as his friend the Mexican writer Carlos Fuentes said, Polanco had been the "backbone" of the forum. Polanco had a multiple myeloma, a cancer of plasma cells, that very few people knew about and something from which he always thought that he would recover. In November they announced the appointment of his son Ignacio as vice president. Ignacio would occupy his place in case Polanco resigned or for any other circumstance hence guaranteeing "the future stability of the society represented by his family" and support for the management team led by Juan Luis Cebrián.

In March of the same year, the Securities Exchange Commission had authorised a takeover bid of PRISA on $20 \%$ of the shares of Sogecable to acquire a majority sufficient to guarantee control. With this, PRISA also managed to double its billing although to do so it was necessary to resort to a 1,600 million euro credit attained by syndicating forty banks. It was necessary to use all the capacity of the group's indebtedness but Polanco thought the economic results would allow them to face it. At the Ortega y Gasset award ceremony Polanco said that "if one day we were the newspaper of the Transition, today we are the Hispanic reference point of the globalisation". In the shareholders meeting later that year he boasted about independence regardless of the doubts some of the shareholders had and the new accusations from the right about favouritisms from the socialist government: he was old enough had been impertinent enough." But what frightened him the most was the right wing's "thirst for revenge," that they 
felt historically legitimised to always exercise power. The reaction to his words was not long in coming and the Partido Popular boycotted the PRISA media.

It was one of his last public appearances. On July $19^{\text {th }}, 2007$ his son Ignacio announced to PRISA's board of administration that for the first time his father could not come to a meeting. Two days later he died. Politicians from all of the political parties, bankers and entrepreneurs, Spanish and foreign journalists from all of the communications media, journalists from his media group, writers, actors and artists all paid their respects at the funeral chapel. His friend the Jesuit Martín Patiño, who had nicknamed him, “Jesús del Gran Poder," presided over his burial.

A few months earlier, already very ill, he had sent a taped greeting to the annual directors' meeting held in Lisbon that year. It was his business will and testament. He told them that they faced difficult challenges ahead but that they could overcome them. They had all the technological, organisational and financial advances they needed. PRISA had not been created to make money nor to gain power, they were just a communications and entertainment company. "We are what we are and we have to take into account not just size but also quality." He also reminded them that it was a "family" company which did not mean that they were self sufficient or that they did not need outside capital or outside directors. But that for more than thirty years it had been a family company vis-a-vis shareholders and family-like regarding the managers, and that had worked. There was no reason to change.

\section{Conclusions}

Jesús de Polanco belonged to a generation of businessmen who started their professional life in the context of the Francoist economic development in the 60's and reached their peak in the final decades of the century. Their business culture, that of those who he referred to as "the old 
school," evolved towards vertical and horizontal integration and the formation of a holding, which he referred to as "acquiring size". He introduced efficient business criteria to some sectors of the activity - publishing books and newspapers - that until then, except for rare exceptions, did not have one. Despite changes in its business structure, the growth of PRISA, the fact that it had gone public and the indebtedness it faced, Polanco hoped that his family would keep control of the company and maintain the culture that it had been born into until the very end. The transformations in PRISA's structure at no time meant that he would abandon the executive presidency.

He was always very conscious of the worldwide technological revolution that took place in the world of journalism and communications. It was something that he was passionate about and that he tried to include in PRISA's evolution: from the inclusion of computers to the newspaper to the development of the television and the digital platforms. He was very aware of the impact of that revolution on the business structure of the sector worldwide. He lived the emergence and the consolidation of the media empires.

The size of the publishing company, Santillana, as well as the media holding - PRISA - was not just the demand of the market in Spain but also the Latin American market. That limit was met for Santillana but not so much for PRISA. The attempts to expand throughout Europe both in the world of journalism as well as television did not advance. Polanco's goal was to become the biggest entertainment and communications group in Spain and Latin America but PRISA was never able to compare itself to the big international conglomerates.

Spanish political evolution always interfered with his activities. He lived the ins and outs of the Francoist institutions, watched their dismantling and saw them replaced by a plural democratic system, progressively conformed by a party system and a new political class. Polanco knew and 
had contact with almost all of the politicians of his time, old Francoists and also the principal actors of the transition. He never held a political position but he became "Jesús del Gran Poder" an epithet that was later used against him by those who accused him of building his economic empire thanks to political favours and then putting it at the service of those who had made it possible. Although he spared no effort in influencing decision-makers when legal changes occurred in the regulation of the multimedia world, his strength stemmed from his capacity to turn something that until then had not been a business into one: the press, the radio, the television. The extreme confidence in independence and credibility that granted him did not let him foresee the actions that a government bent on destroying him could come to adopt. The media and political wars clashed with the unleashed entrepreneurial competition in the communications sector; a sector that was especially sensitive to the decisions of the political powers.

\section{References}

Almirón, Nuria. 2006. "Poder financiero y poder mediático: banca y grupos de comunicación. Los casos del SCH y PRISA (1976-2004)" PhD diss., Departament de Periodisme i Ciències de la Comunicació, Universidad Autònoma de Barcelona.

Baena del Alcazar, Mariano. 1999. Elites y conjuntos de poder en España (1939-1992). Un estudio cuantitativo sobre Parlamento, Gobierno y Administración y gran empresa. Madrid: Tecnos.

Cabrera, Mercedes. 1997. "La modernización política. Los empresarios en la historia de España." Papeles de Economía Española 73:272-284.

Cabrera, Mercedes. 2015. Jesús de Polanco (1929-2007) Capitán de empresas. Barcelona: Galaxia Gutenberg.

Cabrera, Mercedes, ed. 2016. José Ortega Spottorno. Un editor, puente entre generaciones (1916-2016) Madrid: Alianza editorial.

Cabrera, Mercedes, and Fernando del Rey. 2011. El poder de los empresarios. Política y economía en la España contemporánea (1875-2010) Barcelona: RBA.

Cacho, Jesús. 1994. M.C. Un intruso en el laberinto de los elegidos. Madrid: Temas de Hoy. 
Carreras, Albert, Xavier Tafunell, and Eugenio Torres. 2003. "Business History in Spain.” In Business History around the World, edited by F. Amatori, and G. Jones, 332-354. Cambridge: Cambridge University Press.

Cruz, Juan. 1996. Una memoria de El País. Barcelona: Plaza y Janés.

Díaz Herrera, José, and Ramón Tijeras. 1991. El dinero del poder. La trama económica en la España socialista. Madrid: Cambio16.

Fernández, Isabel, and Fernanda Santana. 2000. Estado y medios de comunicación en la España democrática. Madrid: Alianza.

Fernández Clemente, Eloy. 2004. "Las biografías de empresarios en España." Estudos do Século XX (4):59-112.

Fernández Moya, María. 2015. "La internacionalización de los editores. Los mercados exteriores.” In Historia de la Edición en España (1939-1975), edited by J. Martínez Martín, 575-595. Madrid: Marcial Pons.

García Ruiz, José Luis. 2000. “Jesús de Polanco Gutiérrez (1929)” In Los 100 empresarios españoles del siglo XX, edited by Eugenio Torres, 539-543. Madrid: LID.

González Duro, Enrique. 2011. Polanco. El señor de El País. Barcelona: Península.

Hayes, Peter. 2001. Industry and Ideology. IG Farben in the Nazi Era. Cambridge: Cambridge University Press.

Imbert, Gerard, and José Vidal Beneyto, eds. 1986. El País o la referencia dominante. Barcelona: Mitre.

James, Harold. 2001. The Deutsch Bank and the Nazi Economic War against the Jews. Cambridge: Cambridge University Press.

James, Harold, and Jakob Turner, eds. 2002. Entreprise in the Period of Fascism in Europe. UK-USA: Ashgate.

Juliá, Santos. 1997. “Sobre el reduccionismo.” Papeles de Economía Española 73:285-288.

Martínez Martín, Jesús A., ed. 2015. Historia de la edición en España 1939-1975. Madrid: Marcial Pons Historia.

Martínez Soler, José Antonio. 1998. Jaque a Polanco. La guerra digital: un enfrentamiento en las trincheras de la política, el dinero y la prensa. Madrid: Temas de Hoy.

Pan-Montojo, Juan, ed. 2007. "Poderes privados y recursos públicos.” Ayer 66:11-173.

Pérez Díaz, Víctor. 1987. "Los empresarios y la clase política." In El retorno de la sociedad civil, 125174. Madrid: Instituto de Estudios Económicos.

Pérez Ledesma, Manuel. 1997. "Empresarios, políticos e historiadores." Papeles de Economía Española 73:289-291 
Pro Ruiz, Juan. 1997. "De empresarios modernos y malvados patronos en la España del siglo XX." Papeles de Economía Española 73:294-305.

Rey, Fernando del. 2003. "La historia empresarial y la historia política en la España contemporánea.”,Ayer 50:333-353.

Ruiz Torres, Pedro. 2010. "Biografía e historia". "Teoría y práctica de la biografía." Network, París, College d'Espagne.

Sánchez Illán, Juan Carlos. 2015. “Los editores españoles en el exterior. El exilio.” In Historia de la Edición en España (1939-1975), edited by J. Martínez Martín, 549-573. Madrid, Marcial Pons.

Seoane, María Cruz, and Susana Sueiro. 2000. Una historia de EL PAIS y del Grupo Prisa. De una aventura incierta a una gran industria cultural. Barcelona: Plaza y Janés.

Toboso, Pilar. 2017. "Redes y grupos empresariales en el Sindicato vertical franquista." Ayer 105:102128.

Tortella Casares, Gabriel. 2000. "Prólogo.” In Los 100 empresarios españoles del siglo XX, edited by Eugenio Torres, 13-17. Madrid: LID.

Torres, Eugenio, ed. 2000. Los 100 empresarios españoles del siglo XX. Madrid: LID.

Turner, Henry Ashby Jr. 1985. German Big Business and the Rise of Hitler. Oxford: Oxford University Press.

Wiesen, Jonathan. 2001. West German Industry and the Challenge of the Nazi Past, 1945-1955. Carolina: University of North Carolina Press.

\footnotetext{
This is an Open Access article distributed under the terms of the Creative Commons Attribution-Non-Commercial-No Derivatives License (http://creativecommons.org/licenses/by-nc-nd/4.0/), which permits non-comercial re-use and distribution, provided the original work is properly cited, and is not altered or transformed in any way.
} 